\title{
Mútrágyázás hatása a telepített pillangós nélküli gyep botanikai összetételére
}

\author{
1'SZEMÁN LÁSZLÓ-2KÁDÁR IMRE-2RAGÁLYI PÉTER \\ ${ }^{1}$ Szent István Egyetem Gyepgazdálkodási Osztály, Gödöllő \\ ${ }^{2}$ MTA Talajtani és Agrokémiai Kutatóintézet, Budapest
}

\section{Összefoglalás}

Egy mútrágyázási tartamkísérlet 28-36. éveiben (a 28. évben, pillangósvirágú gyepalkotók nélkül 8 fúfajból álló magkeverékkel telepített gyep 1-9. évei alatt, 2001-2009 között) vizsgáltuk az eltérô $\mathrm{N}, \mathrm{P}, \mathrm{K}$ ellátottsági szintek és kombinációk hatását a réti csenkesz vezérnövényú, nyolckomponensú pillangós nélküli gyep botanikai összetételére. A termőhely talaja a szántott rétegben mintegy 3\% humuszt, 3-5\% $\mathrm{CaCO}_{3}$-ot és 20-22\% agyagot tartalmazott. Talajvizsgálatok szerint a termóhely N és K elemekkel közepesen, P és Zn elemekkel viszonylag gyengén ellátottnak minôsült. A kísérlet $4 \mathrm{~N} \times 4 \mathrm{P} \times 4 \mathrm{~K}=64$ kezelést $\times 2$ ismétlést=128 parcellát foglal magában. A talajvíz $13-15 \mathrm{~m}$ mélyen helyezkedik el, a kísérleti terület aszályérzékeny. Főbb eredményeink:

1. A zöld pántlikafú már ki sem kelt, az 1. évben sem tudott elszaporodni. A 3. évben a réti komócsin, 5. évben az angol perje, 6. évben a réti csenkesz és a vörös csenkesz pusztult ki. A csomós ebír borítása az 1. évben becsült 6\%-ról a 6. évre 15\%-ra emelkedett, majd a 9. évre 3\%-ra süllyedt. Előretört az évek során a nádképú csenkesz (26-32\%), a taréjos búzafú (14\%) és a betelepült magyar rozsnok (14\%). A gyomok borítása a kezdeti 1-2\%-ról 6-7\%-ra nőtt a ritkuló, öregedő gyepben. Az összes növényborítottság az elsô években mért 96-99\%-ról a 9. évben 64\%-ra csökkent.

2. A botanikai összetételt drasztikusan módosította az $\mathrm{N} \times \mathrm{P}$ ellátottság. A nádképú csenkesz pl. 2008-ban az $\mathrm{N}_{0} \mathrm{P}_{0}$ kontrollon 34\%, $\mathrm{N}_{1} \mathrm{P}_{1}$ kezelésben $61 \%$, míg az $\mathrm{N}_{3} \mathrm{P}_{3}$ kezelésben $6 \%$ borítást mutatott közepes trágyaigénnyel. Extrém NP-bőséget igényelt ezzel szemben a magyar rozsnok, melynek borítása az NP-kontrollon talált 8\%-ról az $\mathrm{N}_{3} \mathrm{P}_{3}$ kezelésben 28\%-ra nôtt. Hasonlóképpen a taréjos búzafú 0\%-ban fordult 
elő az NP-hiányos, illetve 33\%-ban az $\mathrm{N}_{3} \mathrm{P}_{3}$ kezelésben. Az összes növényborítás 2008-ban (fú+gyom fajok) az NP-kontroll talajon 48\%-ot, az $\mathrm{N}_{1} \mathrm{P}_{1}$ kezelésben 92\%-ot, az NP-túlsúlyos talajon 82\%-ot tett ki. Az átlagos borítás 76\%-nak adódott.

3. A kölcsönhatások évenként eltérhetnek, de irányuk egybecseng, hasonló. Így pl. 2009-ben az összes borítás az NP-kontroll talajon 63\%, az $\mathrm{N}_{1} \mathrm{P}_{1}$ kezelésben 79\%, míg az NP-túlsúlyos talajon 55\% volt. Az átlagos borítottság 64\%-nak adódott. A K-trágyázás érdemben nem befolyásolta a gyep botanikai összetételét (ahogyan a szénahozamokat sem) ezen a K-mal közepesen ellátott vályogtalajon.

Kulcsszavak: telepített gyep, NPK mútrágyázás, botanikai összetétel

\title{
Effect of fertilization on the botanical composition of an established all-grass sward
}

\author{
${ }^{1}$ L. SZEMÁN-2I. KÁDÁR-2P. RAGÁLYI \\ ${ }^{1}$ Szent István University, Department of Grassland Management, Gödölló \\ ${ }^{2}$ Research Institute for Soil Science and Agricultural Chemistry of the Hungarian \\ Academy of Sciences, Budapest
}

\begin{abstract}
Summary
The effects of different N, P and K supply levels and their combinations were examined on the botanical composition of an all-grass sward with seed mixture of eight grass species with meadow fescue as the main species in the $28-36^{\text {th }}$ years (grass was established in the $28^{\text {th }}$ year) of a long term fertilization field experiment, between 2001 and 2009. The calcareous chernozem loamy soil of the growing site contained around $3 \%$ humus, $3-5 \% \mathrm{CaCO}_{3}, 20-22 \%$ clay in the ploughed layer and was originally moderately supplied with available $\mathrm{N}$ and $\mathrm{K}$, and relatively poorly supplied with $\mathrm{P}$ and $\mathrm{Zn}$. The trial included $4 \mathrm{~N} \times 4 \mathrm{P} \times 4 \mathrm{~K}=64$ treatments in 2 replications, giving a total of 128 plots. The groundwater table was at a depth of 13-15 $\mathrm{m}$ and the area was prone to drought. The main results and conclusions can be summarised as follows:

1. Reed canarygrass germinated in the $1^{\text {st }}$ year so poorly that it could not establish. In the $3^{\text {rd }}$ year timothy, in the $5^{\text {th }}$ perennial ryegrass, in the 6 th meadow fescue and red fescue thinned away. Coverage of cocksfoot increased from about $6 \%$ in the
\end{abstract}


first year to $15 \%$ by the $6^{\text {th }}$ year, but by the $9^{\text {th }}$ year it decreased to $3 \%$. Tall fescue (26-32\%), Crested wheatgrass (14\%) and the immigrant smooth brome grass (14\%) invaded through the years. Weed cover grew from the $1-2 \%$ to $6-7 \%$ in the thinning and aging grass. The total coverage decreased from $96-99 \%$ of the $1^{\text {st }}$ year to $64 \%$ of the $9^{\text {th }}$ year.

2. The botanical composition was drastically modified by the $\mathrm{N} \times \mathrm{P}$ supply. Tall fescue cover was for example $34 \%$ in 2008 at the $\mathrm{N}_{0} \mathrm{P}_{0}$ control, $61 \%$ at the $\mathrm{N}_{1} \mathrm{P}_{1}$ treatment, while $6 \%$ at the $\mathrm{N}_{3} \mathrm{P}_{3}$ treatment, so it had moderated $\mathrm{N}$ and $\mathrm{P}$ demand. At the same time smooth brome needed extreme NP supply, rising the $8 \%$ cover at the NP-control to $28 \%$ at the $\mathrm{N}_{3} \mathrm{P}_{3}$ treatment. Similarly the agropyron covered $0 \%$ of the NP-deficient, but $33 \%$ of the $\mathrm{N}_{3} \mathrm{P}_{3}$ treatment. Total coverage in 2008 (grasses + weeds) at the NP-control soil reached $48 \%$, at $\mathrm{N}_{1} \mathrm{P}_{1}$ treatment $92 \%$, at the NP-oversupplied soil $82 \%$. The average cover was $76 \%$.

3. The interactions were different in each year, but their trend was similar. Thus for example in 2009 the total coverage at the NP control soil was $63 \%$, at the $\mathrm{N}_{1} \mathrm{P}_{1}$ treatment $79 \%$, while at NP-overloaded soil $55 \%$. The average cover was $64 \%$. Potassium fertilization did not affect significantly the botanical composition of the grass (neither the hay yields) at this site, which was moderately supplied with K.

Key words: established all-grassland, NPK fertilization, botanical composition

\section{Bevezetés}

Régóta ismert, hogy a trágyázás hatása a gyepen más, mint a szántón. A gyep takarmánytermésének hozamfokozási lehetôségei között meghatározó viszont a tápanyagellátás szakszerú és tudományos alapokon nyugvó rendszeressége. Másként hat a mútrágya a gyep komponenseire, így a füvekre, pillangósokra és a gyomokra. Emiatt a gyepalkotók igénye és tűrôképessége alapján szelektál. Egyes fajok fejlődését segíti, másokét fenntartja, ismét másokét elnyomja. A gyep plasztikusan reagál a környezeti és emberi beavatkozásokra, változtatva botanikai és ásványi összetételét. Eltérô lehet ugyanis az egyes fajok környezettel szembeni igénye, a gyeptársuláson belüli fejlődési stádiuma, összetétele stb., így összességében kevésbé érzékenyen reagál a külső hatásokra. A füvek fejlődési stádiumai a kalászosokéval megegyeznek (Klapp 1965, 1971; Voisin 1961, 1964, 1965).

Általában elfogadott, hogy mérsékelten kedvező viszonyok között, pl. közepes termékenységú talajon a fényért és a tápanyagokért folyó kompetíció is mér- 
sékelt. Ezért itt viszonylag nagyszámú mezotróf faj élhet együtt oligotróf és eutotróf fajokkal. A kaszáló gyepeken bőséges N-kínálat esetén a kevés, de gyorsnövésú faj, a szálfüvek kiszorítják a lassabban fejlődő aljfüvek és a „virágzó” kétszikú fajok többségét. Hasonló hatású a P-trágyázás. A leginkább fajgazdag gyepek általában a legszegényebbek a talaj P-tartalmát tekintve. A P a N-nel együtt közvetlen befolyásolással bír a fajok közötti versengésre (Peters és Janssens 1998, Bánszki 1988, 1997).

Peters és Janssens (1998) szerint, ha az $\mathrm{NH}_{4}$-acetát+EDTA oldható P-tartalom a feltalajban meghaladja az $50 \mathrm{mg} / \mathrm{kg}$ értéket (a jó kielégítố ellátottságot), természetes gyepekben a fajok száma 20 alatt marad. Persze extrém tápelemhiányos, terméketlen termôhelyen már csak kevés, lassan fejlődő faj képes életben maradni. Itt tehát a fajok száma szintén kevés, korlátozott. Az extrém P-hiányos talajon kevés a pillangós, kicsi a N-kötés, kicsi a mineralizáció, a talajbani lebomlás. A P-szegény termőhelyet a gyorsnövésú eutróf fajok kevéssé tudják hasznosítani, nem képesek versenyezni a lassan növekvő oligotróf és mezotróf fajokkal.

A fajgazdag „vadvirágos” gyep társadalmi igényeket elégít ki. Ilyen gyep már nem telepíthetố könnyen oldható P-tartalommal jól ellátott területeken. Hacsak a felső $20 \mathrm{~cm}$ talajréteget ki nem cseréljük. A „vadvirágos” fajgazdag rét vagy gyep telepítésénél kizárandó tényezốk a nagy szervesanyag-tartalom, a bôséges szervestrágya vagy NP-mútrágya alkalmazása, pillangósok vagy a környezet nagy légköri N-terhelése. A K-mútrágya a K-ban szegény homoki gyepeken válthat ki hasonló módosulásokat a faji összetételben hazai és nemzetközi utalások szerint (Barcsák 1999, 2004, Geisler 1988, Nagy 2003, Schüpbach 1990, Vinczeffy 1998, 1999).

A tartamhatásokat figyelembe véve, talán a legkisebb befektetéssel, a mútrágyákkal befolyásolhatjuk gyökeresen a gyepek összetételét. McLeod (1965) tenyészedény kísérletben vizsgálta az egyes NxK mútrágya-kombinációk hatását a herefüves keverék összetételére. Az egyes növényfajok tiszta és kevert állományában kapott terméseinek hányadosát „,versengési indexnek” tekintette. A K fookként a K-igényes pillangós lucerna tömegét növelte. Itthon Bánszki (1991) karbonátos csernozjomon beállított szabadföldi kísérletében, a pillangósokban gazdag gyepkeverék mútrágyázott kezeléseiben a pillangósok aránya 32\%-ról 10\%-ra csökkent a N-bőség nyomán a 3 év alatt. Szemán (2002) szabadföldi kísérletében a $22 \%$ borítást képviselô pillangósok a kísérlet 4. évére kipusztultak a N-trágyázással. 
Munkánk célja, hogy egy (Kádár Imre tervei alapján végzett) 35 éves NPK mứtrágyázási tartamkísérletben vizsgáljuk az eltérô mútrágyázási/tápláltsági szituáció hatását a 8 komponensú pillangós nélküli gyep botanikai összetételére a gyepkísérlet 9 éve alatt. A gyepkeverék egyaránt tartalmazott laza bokrú szálfüveket (réti csenkesz, nádképú csenkesz, réti komócsin, csomós ebír és laza bokrú aljüveket (angol perje, taréjos búzafú), valamint tarackos szálfüvet (zöld pántlikafü) és tarackos aljfüvet (vörös csenkesz).

\section{Anyag és módszer}

A kísérletet 1973 ôszén állítottuk be Mezőföldön, a MTA Talajtani és Agrokémiai Kutatóintézet nagyhörcsöki kísérleti telepén. A termőhely löszön képzôdött karbonátos csernozjom talaja a szántott rétegben mintegy 3-5\% $\mathrm{CaCO}_{3}$-ot és 3\% humuszt tartalmaz. A pH(KCl) 7,3, az AL- $\mathrm{P}_{2} \mathrm{O}_{5} 60-80 \mathrm{mg} / \mathrm{kg}$, AL-K ${ }_{2} \mathrm{O}$ 140-160 mg/kg, KCl-oldható Mg 150-180 mg/kg. Ami a KCl+EDTAoldható mikroelemeket illeti a Mn $80-150 \mathrm{mg} / \mathrm{kg}$, a Cu 2-3 mg/kg, a Zn 1-2 $\mathrm{mg} / \mathrm{kg}$ értékkel jellemezhetô. A hazai szaktanácsadásunkban irányadó határértékek alapján ezek az adatok igen jó Mn, kielégítő Mg és Cu, közepes N és K, valamint gyenge P és Zn ellátottságról tanúskodnak. A talajvíz szintje 13-15 m mélyen található, a kísérleti terület az Alföldhöz hasonlóan aszályérzékeny.

A N-t megosztva, felét ôsszel, felét tavasszal alkalmaztuk pétisó formájában 0, 100, 200, $300 \mathrm{~kg} / \mathrm{ha}$ /év N-adagban. A P és K trágyázás 0, 500, 1000, 1500 $\mathrm{kg} / \mathrm{ha} \mathrm{P}_{2} \mathrm{O}_{5}$ illetve $\mathrm{K}_{2} \mathrm{O}$ adaggal történik, 5-10 évente ismételve a feltöltést. Legutóbb 1999 ôszén végeztünk PK feltöltő trágyázást. A N, P és K mútrágyákat 4-4 szinten adagolva 1973 ôszén minden lehetséges kombinációt beállítottunk $4 \mathrm{~N} \times 4 \mathrm{P}=16 \times 4 \mathrm{~K}=64$ kezelés $\times 2$ ismétlés=128 parcellában. A parcellák mérete $6 \times 6=36 \mathrm{~m}^{2}$, elrendezésük kevert faktoriális. A kísérleti terv, illetve az alkalmazott mútrágyázás lehetôvé tette, hogy valamennyi olyan tápláltsági állapotot (gyenge, közepes, kielégítő, túlzott) és azok változatait létrehozzuk, amelyek a gyakorlatban is előfordulnak, vagy táblaszinten a jövőben elôfordulhatnak.

A 33 év alatt 0, 3200, 6400, $9600 \mathrm{~kg} / \mathrm{ha}$ N-t használtunk fel. A növények által fel nem vett $\mathrm{N}$ 40-60\%-át $\mathrm{NO}_{3}-\mathrm{N}$ formában tudtuk korábban kimutatni a túltrágyázott talajon. Az időnként végzett mélyfúrásaink szerint a $\mathrm{NO}_{3}-\mathrm{N} 20-30$ cm/év sebességgel szivároghat lefelé, a kísérlet 17. illetve 22. éve után a bemosódás mélysége elérte e termőhelyen a 6 métert (Kádár és Németh 1993, 
Németh és Kádár 1999). Megemlítjük, hogy 2001-ben az 1 éves gyep alatt a feltalaj $\mathrm{NO}_{3}$-N készlete drasztikusan lecsökkent, még a $300 \mathrm{~kg} / \mathrm{ha}$ /év N kezelésekben is, ami visszavezethetô jelentôs részben a növénybe épült hatalmas $\mathrm{N}$-mennyiségekre. A két kaszálással felvett $\mathrm{N}$ földfeletti mennyisége megközelítette a $400 \mathrm{~kg} / \mathrm{ha}$ tömeget. Akár hasonló lehetett a gyökerekbe épült $\mathrm{N}$ menynyisége is.

A 3 évtized alatt $0,1500,3000,4500 \mathrm{~kg} / \mathrm{ha} \mathrm{P}_{2} \mathrm{O}_{5}$, illetve $2500,5000,7500$ $\mathrm{kg} / \mathrm{ha} \mathrm{K}_{2} \mathrm{O}$ felhasználásra került sor, mely tükröződik a feltalaj ammóniumlaktát oldható PK-készletén. Egyaránt megtalálható a gyenge, közepes, igen jó és a káros P-ellátottság. Hasonló a helyzet a talaj mobilis K-készletét illetôen. Talajvizsgálatokat 2005 ôszén végeztünk. A kísérletben alkalmazott kezeléseket és a talaj szántott rétegének oldható elemtartalmát az 1. táblázat tekinti át.

1. táblázat. Kezelések és hatásuk a talaj szántott rétegének AL-oldható elemkészletére 2005-ben

(Karbonátos csernozjom vályogtalaj, Nagyhörcsök, Mezóföld)

\begin{tabular}{|c|c|c|c|c|c|c|}
\hline \multirow[t]{2}{*}{$\begin{array}{c}\text { Mútrágyázás és } \\
\text { talajvizsgálat } \\
\text { (1) }\end{array}$} & \multicolumn{4}{|c|}{$\begin{array}{c}\text { Kezelések, illetve } \\
\text { mútrágyázási szintek } \\
(2)\end{array}$} & \multirow[t]{2}{*}{$\begin{array}{c}\mathrm{SzD}_{5 \%} \\
(3)\end{array}$} & \multirow[t]{2}{*}{$\begin{array}{c}\text { Átlag } \\
(4)\end{array}$} \\
\hline & 0 & 1 & 2 & 3 & & \\
\hline N kg/ha/év (5) & 0 & 100 & 200 & 300 & - & 150 \\
\hline N kg/ha/32 év (6) & 0 & 3200 & 6400 & 9600 & - & 4800 \\
\hline $\mathrm{P}_{2} \mathrm{O}_{5} \mathrm{~kg} / \mathrm{ha} / 32$ év (7) & 0 & 1500 & 3000 & 4500 & - & 2250 \\
\hline $\mathrm{K}_{2} \mathrm{O} \mathrm{kg} / \mathrm{ha} / 32$ év (8) & 0 & 2500 & 5000 & 7500 & - & 3750 \\
\hline $\mathrm{AL}-\mathrm{P}_{2} \mathrm{O}_{5} \mathrm{mg} / \mathrm{kg}(9)$ & 87 & 214 & 444 & 704 & 56 & 362 \\
\hline $\mathrm{AL}-\mathrm{K}_{2} \mathrm{O} \mathrm{mg} / \mathrm{kg}(10)$ & 158 & 201 & 279 & 363 & 39 & 250 \\
\hline
\end{tabular}

Table 1. Treatments and their effects on the soluble PK-content in the plow layer. (Calcareous loamy chernozem, Nagyhörcsök, Mezőföld region). (1) Fertilization and soil analysis, (2) Treatments or fertilization levels, (3) $\mathrm{LSD}_{5 \%}$, (4) Mean, (5) N kg/ha/years, (6) $\mathrm{N} \mathrm{kg} / \mathrm{ha} / 32$ years, (7) $\mathrm{P}_{2} \mathrm{O}_{5} \mathrm{~kg} / \mathrm{ha} / 32$ years, (8) $\mathrm{K}_{2} \mathrm{O} \mathrm{kg} / \mathrm{ha} / 32$ years, (9) Ammoniumlactate soluble AL- $\mathrm{P}_{2} \mathrm{O}_{5},(10) \mathrm{AL}-\mathrm{K}_{2} \mathrm{O} \mathrm{mg} / \mathrm{kg}$.

Az elmúlt évtizedekben igyekeztünk minden fontosabb szántóföldi növényfaj agrokémiájával foglalkozni és feltárni a tápláltsági állapot, valamint a termés, terméselemek, ásványi összetétel, gyomosodás, betegségellenállóság, minôségi jellemzók közötti számszerú összefüggéseket, megismerni a növényi 
és talajbani optimumokat, orientálni a szaktanácsadást. Erre utal a kísérlet növényi sorrendje, amely a 2. táblázatban tanulmányozható.

2. táblázat. Növényi sorrend a kísérletben 1974-2009 között

(Karbonátos csernozjom vályogtalaj, Nagyhörcsök, Mezöföld)

\begin{tabular}{rclccl}
\hline $\mathrm{N}^{\circ}$ & $\begin{array}{c}\text { Évek } \\
(1)\end{array}$ & $\begin{array}{c}\text { Kísérleti növény } \\
(2)\end{array}$ & $\mathrm{N}^{\circ}$ & $\begin{array}{c}\text { Évek } \\
(1)\end{array}$ & $\begin{array}{c}\text { Kísérleti növény } \\
(2)\end{array}$ \\
\hline 1. & 1974 & Búza (3) & 21. & 1994 & Sárgarépa (21) \\
2. & 1975 & Búza (3) & 22. & 1995 & Rozs (22) \\
3. & 1976 & Kukorica (4) & 23. & 1996 & Köles (23) \\
4. & 1977 & Kukorica (4) & 24. & 1997 & Bab (24) \\
5. & 1978 & Burgonya (5) & 25. & 1998 & Olaszperje (25) \\
& & & & & \\
6. & 1979 & Ószi árpa (6) & 26. & 1999 & Olaszperje (25) \\
7. & 1980 & Zab (7) & 27. & 2000 & Spenót (26) \\
8. & 1981 & Cukorrépa (8) & 28. & 2001 & Gyep (27) \\
9. & 1982 & Napraforgó (9) & 29. & 2002 & Gyep (27) \\
10. & 1983 & Mák (10) & & & \\
& & & 30. & 2003 & Gyep (27) \\
11. & 1984 & Repce (11) & 31. & 2004 & Gyep (27) \\
12. & 1985 & Mustár (12) & 32. & 2005 & Gyep (27) \\
13. & 1986 & Sörárpa (13) & 33. & 2006 & Gyep (27) \\
14. & 1987 & Olajlen (14) & 34. & 2007 & Gyep (27) \\
15. & 1988 & Szója (15) & 35. & 2008 & Gyep (27) \\
& & & & & \\
16. & 1989 & Rostkender (16) & 36. & 2009 & Gyep (27) \\
17. & 1990 & Borsó (17) & 37. & 2010 & Gyep (27) (Terv.) \\
18. & 1991 & Tritikále (18) & 38. & 2011 & Gyep (27) (Terv.) \\
19. & 1992 & Cirok (19) & 39. & 2012 & Gyep (27) (Terv.) \\
20. & 1993 & Silókukorica (20) & 40. & 2013 & Gyep (27) (Terv.) \\
\hline
\end{tabular}

Table 2. Crop sequence in the experiment, 1974-2009. (Calcareous loamy chernozem, Nagyhörcsök, Mezőföld region). (1) Years, (2) Crop species, (3) Winter wheat, (4) Maize, (5) Potato, (6) Winter barley, (7) Oat, (8) Sugarbeet, (9) Sunflower, (10) Poppy, (11) Rapeseed, (12) Mustard, (13) Spring barley, (14) Oilflax, (15) Soybean, (16) Flax, (17) Pea, (18) Triticale, (19) Sorghum, (20) Fodder maize, (21) Carrot, (22) Rye, (23) Millet, (24) Bean, (25) Italian ryegrass, (26) Spinach, (27) Grasses. 
A kísérlet első 2 évtizedének fôbb eredményeit „A növénytáplálás alapelvei és módszerei" c. kézikönyv (Kádár 1992) foglalta össze. Az egyes években nyert kísérleti adatok növényfajonként megjelentek, illetve megjelennek a Növénytermelés, illetve az Agrokémia és Talajtan c. folyóiratok hasábjain.

A gyep telepítését a spenót betakarítása után 2000. szeptember 20-án végeztük el 8 komponensből álló gyepvetőmag keverékkel. A vetőmag a Szarvasi Gyepnemesítő Telep (Bikazug) 1999. évi terméséből származott. A viszonylag sok komponens azt a célt szolgálta, hogy kellô borítottság alakulhasson ki és tájékozódjunk arról, mely fajok alkalmasak e termóhelyre.

Az alkalmazott fứmag keverék adag $60 \mathrm{~kg} / \mathrm{ha}$ volt. A vetőmag keverék fajonkénti tömegéből, a fajok ezerszemtömege alapján meghatároztuk az egyes gyepalkotók telepítés után várható növényállomány arányát. Amint a 3. táblázatban látható, vezérnövényünk a réti csenkesz 15 kg-mal, növényarány szerint 18\%-ot képvisel. Növényarány szerint a nádképú csenkesz 12\%, az angolperje 13\%, a taréjos búzafú 6\%, a vörös csenkesz 8\%, réti komócsin 19\%, zöld pántlikafú $15 \%$ és a csomós ebír 9\% részesdést adott. A vezérnövény virágzása előtti, bimbózási fenofázisban kaszáltunk. A parcellák szegélyétől 1,4 m-eket jobbról és balról lehagyva 3,2×6=19,2 m² nettó parcellák területét értékeltük a gyeptelepítés talaj előkészítése idején előforduló, az eke általi talajáthordás hatásának kizárása céljából. Laboratóriumi vizsgálatokra, parcellánként 20 helyrôl a fúkasza után, átlagmintákat vettünk. A mintáknak mértük a friss és légszáraz tömegét $50^{\circ} \mathrm{C}$-on történt szárítást követően, majd finomra ôröltük és 23-25 elemre vizsgáltuk cc. $\mathrm{HNO}_{3}+\mathrm{cc} \cdot \mathrm{H}_{2} \mathrm{O}_{2}$ roncsolás után, ICP technikát alkalmazva. A N-tartalmat hagyományos cc. $\mathrm{H}_{2} \mathrm{SO}_{4}+\mathrm{cc} \cdot \mathrm{H}_{2} \mathrm{O}_{2}$ feltárásból határoztuk meg az ISO 11261 (1995) szerint módosított Kjeldahl (1891) eljárással. $\mathrm{A} \mathrm{NO}_{3}$-N készletét 1:800 arányú desztillált vizes kivonatból mértük Thammné (1990) által ajánlott módszerrel.

Kaszálásonként és parcellánként az elsố növedékben bonitáltuk a növényállomány fejlettségét, borítottságát, magasságát. Az egyes komponensek változását dr. Szemán László (SZIE, Gödöllő) és dr. Vinczeffy Imre (DE, Debrecen), a gyomosodást dr. Radics László (KÉE, Budapest), a takarmányérték minôségvizsgálatokat dr. Gyôri Zoltán (DE, Debrecen) végezte. A telepítés elôtt talajmintákat vettünk a szántott rétegból parcellánként 20-20 pontminta/lefúrás egyesítésével. A mintákban meghatároztuk a NH4-acetát+EDTA-oldható makro- és mikroelemeket Lakanen és Erviö (1971), valamint az $\mathrm{NH}_{4}$-laktát-oldható PK tartalmat Egnér et al. (1960) szerint. 
3. táblázat. A kísérletben elvetett fúmagkeverék összetétele

\begin{tabular}{|c|c|c|c|}
\hline $\mathrm{N}^{\mathrm{o}}$ & $\begin{array}{c}\text { Komponensek } \\
\text { (1) }\end{array}$ & $\begin{array}{c}\text { Mag } \\
\mathrm{kg} / \mathrm{ha} \\
(2)\end{array}$ & $\begin{array}{c}\text { Fû faj arány } \\
\% \\
\text { (3) }\end{array}$ \\
\hline 1. & Réti csenkesz (Festuca pratensis) (5) & 15,0 & 18 \\
\hline 2. & Nádképú csenkesz (Festuca arundinacea) (6) & 12,6 & 12 \\
\hline 3. & Angolperje (Lolium perenne) (7) & 12,6 & 13 \\
\hline 4. & Taréjos búzafú (Agropyron pectinatum) (8) & 5,4 & 6 \\
\hline 5. & Vörös csenkesz (Festuca rubra) (9) & 3,6 & 8 \\
\hline 6. & Réti komócsin (Phleum pratense) (10) & 3,6 & 19 \\
\hline 7. & Zöld pántlikafú (Phalaris arundinacea) (11) & 3,6 & 15 \\
\hline \multirow[t]{2}{*}{8.} & Csomós ebir (Dactylis glomerata) (12) & 3,6 & 9 \\
\hline & Összesen (4) & 60,0 & 100 \\
\hline
\end{tabular}

Table 3. Seed mixture of sown grass species. (1) Components, (2) Seed kg/ha, (3) Grass species rate $\%$, (4) Total, (5) Meadow fescue, (6) Tall fescue, (7) Perennial ryegrass, (8) Crested wheatgrass, (9) Red fescue, (10) Timothy, (11) Reed canarygrass, (12) Cocksfoot.

A havi, negyedéves és az éves csapadékösszegek adatait a 4. táblázatban tanulmányozhatjuk. Amint látható, a vizsgált 9 évből 3 év (2001, 2004, 2005) volt az átlagosnál csapadékosabb, míg 5 évben a lehullott csapadék mennyisége a sokévi, a telepen mért 47 éves átlag alatt maradt. Az 1. kaszálás általában május hóban történt, míg a 2 . kaszálásra a III. negyedév valamely hónapjában került sor a csapadék függvényében. A kísérlet elsô 5 évének fốbb eredményeit korábbi közleményeink foglalják össze (Kádár 2004a,b, 2007a,b). Megemlítjük, hogy döntónek a N-trágyázás mutatkozott, melynek hatására a N-kontroll parcellán mért 1-2 t/ha szénatermés 6-8 t/ha-ra ugrott. A P és a K adagolásával átlagosan 0,5-0,5 t/ha széna többlet-produkciót kaptunk az 1 . kaszálások idején. A 2. kaszálás hozamait csak a N-kezelések befolyásolták. A 2003, 2007, 2008 években 2. kaszálásra nem került sor, a fú kisült, gazdaságilag értékelhetô terméseket nem adott. 
4. táblázat. A havi, negyedéves és az éves csapadékösszegek adatai, mm (Mészlepedékes csernozjom vályogtalaj, Nagyhörcsök, Mezöföld)

\begin{tabular}{|c|c|c|c|c|c|}
\hline $\begin{array}{l}\text { Idószak } \\
\text { (1) }\end{array}$ & 2001 & 2002 & 2003 & 2004 & 2005 \\
\hline Január (3) & 44 & 11 & 29 & 32 & 16 \\
\hline Február (4) & 0 & 18 & 34 & 46 & 36 \\
\hline Március (5) & 62 & 14 & 5 & 61 & 29 \\
\hline I. negyedév (6) & 106 & 43 & 68 & 139 & 81 \\
\hline Április (7) & 47 & 41 & 22 & 88 & 53 \\
\hline Május (8) & 17 & 55 & 30 & 28 & 15 \\
\hline Június (9) & 47 & 32 & 18 & 113 & 38 \\
\hline II. negyedév (10) & 111 & 128 & 70 & 229 & 106 \\
\hline Július (11) & 80 & 64 & 88 & 38 & 124 \\
\hline Augusztus (12) & 129 & 84 & 25 & 26 & 204 \\
\hline Szeptember (13) & 113 & 65 & 27 & 17 & 56 \\
\hline III. negyedév (14) & 322 & 213 & 140 & 81 & 384 \\
\hline Október (15) & 0 & 32 & 92 & 59 & 0 \\
\hline November (16) & 57 & 32 & 39 & 58 & 32 \\
\hline December (17) & 25 & 28 & 16 & 41 & 46 \\
\hline IV. negyedév (18) & 82 & 92 & 147 & 158 & 78 \\
\hline Éves összeg (19) & 621 & 476 & 425 & 607 & 649 \\
\hline $\begin{array}{c}\text { Idôszak } \\
\text { (1) }\end{array}$ & 2006 & 2007 & 2008 & 2009 & $\begin{array}{l}\text { *Átlag } \\
\text { (2) }\end{array}$ \\
\hline Január (3) & 32 & 18 & 11 & 45 & 26 \\
\hline Február (4) & 44 & 35 & 4 & 45 & 29 \\
\hline Március (5) & 26 & 36 & 50 & 21 & 34 \\
\hline I. negyedév (6) & 102 & 89 & 65 & 111 & 89 \\
\hline Április (7) & 28 & 0 & 18 & 0 & 33 \\
\hline Május (8) & 37 & 84 & 30 & 8 & 34 \\
\hline Június (9) & 86 & 45 & 82 & 106 & 63 \\
\hline II. negyedév (10) & 151 & 129 & 130 & 114 & 130 \\
\hline Július (11) & 43 & 22 & 50 & 19 & 63 \\
\hline Augusztus (12) & 102 & 97 & 14 & 37 & 85 \\
\hline Szeptember (13) & 37 & 36 & 45 & 26 & 50 \\
\hline III. negyedév (14) & 182 & 155 & 109 & 82 & 198 \\
\hline Október (15) & 21 & 52 & 21 & 42 & 34 \\
\hline November (16) & 14 & 61 & 23 & 65 & 39 \\
\hline December (17) & 5 & 59 & 50 & - & 34 \\
\hline IV. negyedév (18) & 40 & 172 & 94 & - & 108 \\
\hline Éves összeg (19) & 475 & 545 & 398 & - & 450 \\
\hline
\end{tabular}

*Átlag: a telepen mért 47 éves átlagok

Table 4. Monthly, quarterly and yearly sums of precipitation, $\mathrm{mm}$. (Calcareous loamy chernozem, Nagyhörcsök, Mezőföld region). (1) Period, (2) Average, (3) January, (4) February, (5) March, (6) Sum of $1^{\text {st }}$ quarter, (7) April, (8) May, (9) June, (10) Sum of $2^{\text {nd }}$ quarter, (11) July, (12) August, (13) September, (14) Sum of $3^{\text {rd }}$ quarter, (15) October, (16) November, (17) December, (18) Sum of $4^{\text {th }}$ quarter, (19) Yearly sum. *Average of 47 years at the experimental site. 


\section{Eredmények értékelése}

A felvételezésekre az 1. kaszálás idején került sor. Az elvetett fúfajok átlagos borítottságát évenként és parcellánként becsültük meg, a \%-os borítottság adatait statisztikailag értékeltük. Az 5. táblázatban egy áttekintést adunk a gyepalkotó fúfajok borítottsági \%-ainak alakulásáról az évek függvényében és a kísérlet fóátlagainak tükrében. A továbbiakban megkíséreljük röviden bemutatni a botanikai összetétel változásait az idő függvényében, gyepalkotó komponensenként. A fajokat Gruber (1960), Szabó (1977), Szemán (2007) és Vinczeffy (1998) nyomán jellemezzük.

Réti csenkesz. (Festuca pratensis Huds.) Vetéskori 25\% maggal és 18\% növényaránnyal vezérnövényként szerepelt 2000 szeptemberében. Bokros szálfú erôteljes gyökérzettel. Közepes vízigényú (mezophil), szárazságtúrô, de az árnyékot és a tartós aszályt nem igazán bírja. Hosszú életú, Gruber (1960) szerint 5-12 évig is fennmaradhat. Viszonylag trágyaigényes. Kísérletünk első 2 évében borítottsága 25-27\% körül alakul, a vetett mag \%-ának megfelelően. A 3. év után visszaszorul és a 6 . évtôl részaránya elenyészó a gyepben.

Nádképú csenkesz. (Festuca arundinacea Schreb.) A vetéskori 21\% maggal 12\% növényarányt képviselt 2000 szeptemberében. Bokros szálfú, zsombékszerú sứrú bokrokkal. Üde, nyirkos talajon, réteken gyakori, de megfelelő tápanyag ellátás mellett jó a szárazságtúrése. Száraz fekvésú húsmarhalegelőkön az augusztusi kisülési idôszakban is legeltethetô gyepet biztosít. Tápanyagellátás nélkül gyenge termôképességú és kiveszik a száraz fekvésú, extenzív gazdasági gyepekbôl. Korán és jól sarjad, de kevés fajjal társul. Trágyaigényességérôl nem közölnek adatokat. A réti csenkeszhez hasonlóan hosszú életú. Kísérletünkben folyamatosan elôretört, részaránya nôtt az első 6-8 év folyamán. A 9. évben a borítási \% visszaesik, de még mindig meghaladja a vetett mag \%-os arányát.

Angolperje. (Lolium perenne L.) Vetéskor maggal 21\%-ot és növényarány szerint 13\%-ot képviselt a keverékben. Bokros aljfú közepes vízigénnyel. Az aszályt azonban nem túri. Sarjadása gyors. Viszonylag trágyaigényes. Hazai viszonyok között 4-8 évig kitart, de a kedvezóen enyhe és nedves éghajlaton, enyhén savanyú talajon (Angliában) akár 20-25 évig is díszlik. Legeltetés és taposás igényes, a legelőben hosszú életú gyepalkotó, de kaszálógyepekben a 3. év után kiritkul és eltúnik a növényállományból. Kísérletünkben 3 éven át átlagos borítása arányos volt a vetett mag mennyiségével, majd a 4 . évben borítása felére csökkent. Az 5., illetve a 6. évre gyakorlatilag kipusztult. 


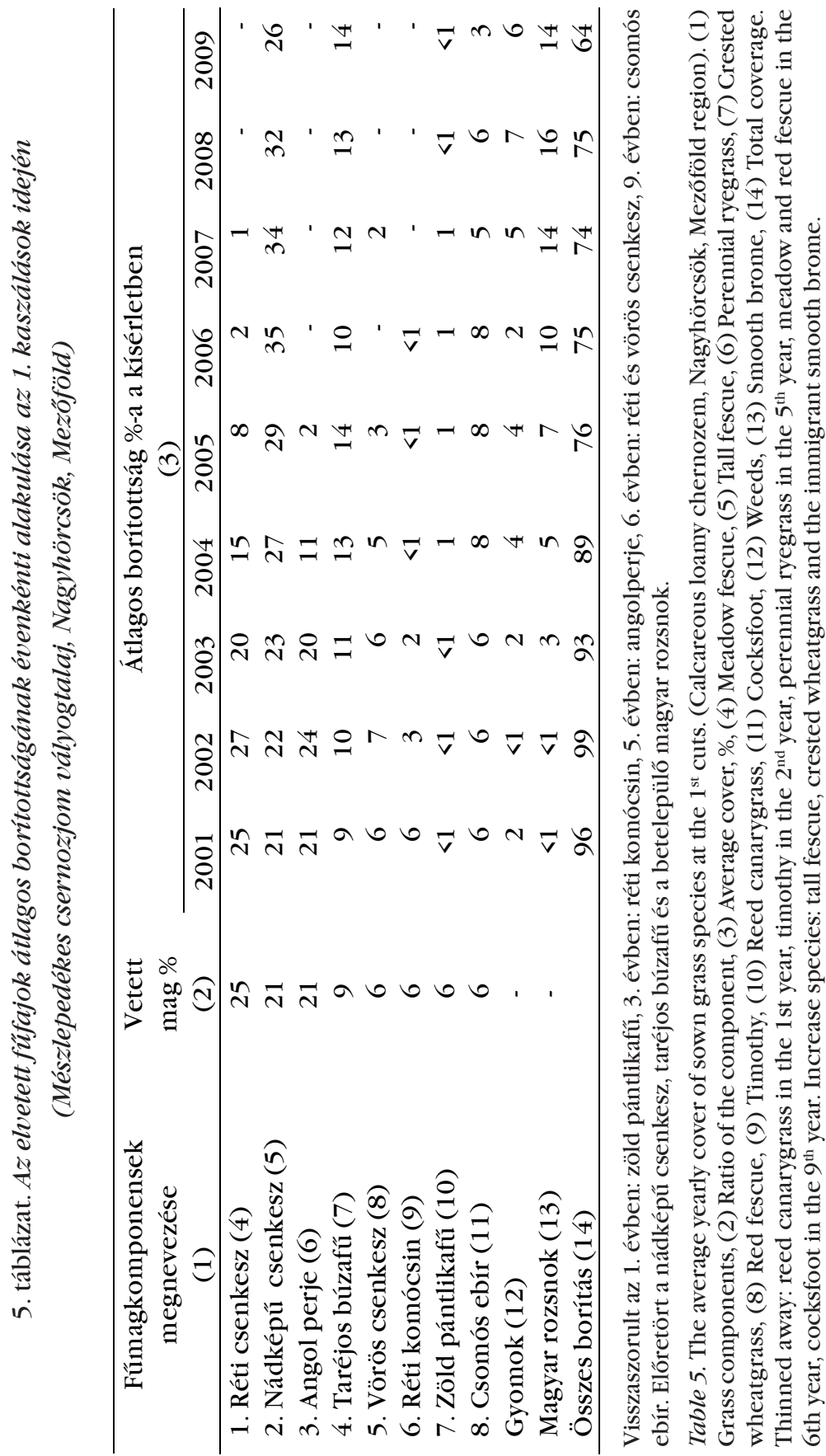


Taréjos búzafú. (Agropyron pectinatum (M.B.) R. etSch.) Vetéskor 6\% növényarányt képviselt a keverékben. Lazabokrú aljfú, nagytömegú gyökérrel, melyek 2 m-ig lehatolhatnak. Ideális számára a homokos vályogtalaj, ahol 10-15 évig is kitart. Szárazságtúrô és hatékony vízhasznosító. Míg pl. Gruber (1960) szerint a lucerna mintegy 800, a magyar rozsnok 600, a taréjos búzafú 400 liter vizet használ $1 \mathrm{~kg}$ szárazanyag képzéséhez. Trágyaigényérôl nem közölnek adatokat. Kísérletünkben ez a faj némileg elôretört és a 9. évben is mintegy 50\%-kal meghaladja a vetéskori borítottságát.

Vörös csenkesz. (Festuca rubra L.) A vetómag keverékben 6\%-ot képviselt 8\% növényaránnyal. Tarackos aljfú. Savanyú talajon, hegyi réteken 7-8 évig elél. Szárazság tû́rô, mészkerülő és N-kedvelô. Kísérleti viszonyaink között a vörös csenkesz 4 éven át tartotta vetéskori pozícióját. Az 5 . évet követóen már csak nyomokban fordul elô, illetve 2007 után a szálfüvek előre törésének következtében kipusztult.

Réti komócsin. (Phleum pratense L.) A vetômag keverékben 6\%-ot képviselt, de $19 \%$ telepítési arányt adhatott volna a növényborításban. Bokros szálfú. Fóként üde réti talajon díszlik. Kísérletünkben borítottsága már a 2. évben mérséklődött, míg a 3. év után kipusztult. Kiritkulását, illetve korai pusztulását a 2003. évi aszály is gyorsíthatta. Trágyaigényességérôl nem közöltek adatokat az említett hazai kézikönyvek, illetve szerzók.

Zöld pántlikafú. (Phalaroides arundinacea L.) Az elvetett vetômagban 6\%-ot növényarány szerint pedig 15\%-ot képviselt. Tarackos szálfú. Termóhelyét tekintve nyirkos talajon fejlôdik igazán és ott társulás alkotó. Kifejezetten N-igényes és vízigényes. Megfelelố tápanyag ellátás mellett jól túri a szárazságot ezért száraz fekvésú húsmarhalegelőnek tiszta fajú vetéssel telepítik. Öszi telepítésben fagyérzékeny. Kísérletünkben már az 1. évtől csak nyomokban volt kimutatható, tehát nem volt képes igazán megtelepedni.

Csomós ebír. (Dactylis glomerata L.) A vetőmag keverékben 6\%-ot képviselt 9\%-ot jelentố növényaránnyal 2000 ôszén. Lazabokrú szálfú kb. 1 m-ig lehatoló gyökérzettel. Elöregedve zsombékos gyepet ad, borítása csökken. Szárazabb területre való. Jól túri a hosszú szárazságot és az árnyékolást is. A N-trágyázást különösen meghálálja. Tiszta vetésben Bánszki (1991) a termését megsokszorozta mútrágyákkal. Kísérletünkben 8 éven át tartotta vetéskori pozícióját, sôt 2006-ban borítása 15\%-ra ugrott. Az utolsó felvétel idején 2009-ben azonban már 3\%-ra szorult vissza. 
Magyar/Árva rozsnok. (Bromus inermis Leyss.) A vetőmag keverékben nem szerepelt. Betelepült faj. Tarackos szálfú. Kiválóan társul, ajánlott száraz legelőkre és extrém körülmények közé. Mészkedvelő, 10-12 évig fennmaradhat. Gyökérzete $2 \mathrm{~m}$-ig is lehatol. Trágyaigényesnek tekintett faj. Betelepülésének, terjedésének folyamata jól nyomon követhetô. A kísérlet 89. éveiben már 14-16\%-os borítást mutat.

Az 5. táblázatban közölt eredményekbôl az is kiolvasható, hogy a gyep öregedésével az áltagos borítottság az elsô években becsült 96-99\%-ról 64\%-ra esett vissza a 9. évre. A gyomosodás viszont az 1-2\%-ról 6\%-ra emelkedett a kísérlet átlagában. A gyomok fôként az erôs NP-hiányos kezelésben szaporodtak el, ahol a gyep kiritkult. Másrészrôl az erôs NP-túlsúly nyomán, ahol a gyep foltosan szintén ritkul, zsombékosodik. A 9. évre 3 faj a meghatározó komponens a gyepben: nádképú csenkesz, taréjos búzafú és a betelepült rozsnok. Tehát a 2 bokros és a betelepült tarackos szálfú. Ezt követi a gyom és még említésre méltó a csomós ebír.

Most lássuk, hogyan hat a trágyázás az egyes fajokra, azok mely talajon versenyképesek, mennyiben trágyaigényesek. A K-trágyázás hatása elhanyagolható volt ezen a K-mal közepesen ellátott homokos vályogtalajon. Eredményeinket ezért kétirányú táblázatokban és évenként az NxP ellátottsági szintek függvényében közöljük 2007., 2008., 2009. években, illetve a 6., 7. és 8. táblázatokban.

2007. május 18-án az 1. kaszálás idején uralkodó faj a nádképú csenkesz. A borítása 10-60\% között változik az NP-ellátottsági szinteken. A 60\% körüli maximális borítást a $100 \mathrm{~kg} / \mathrm{ha}$ /év N-adagnál mutatja, tehát mérsékelten N-igényes. A növekvô P-ellátás önmagában nem módosítja a borítást. Tehát nem P-igényes, de N-hiányában a talaj extrémen nagy oldható P-tartalma sem okoz igazolható depressziót. Az együttes NP-túlsúly tápláltsági szituációban viszont rendkívüli módon visszaszorul, az NP-túlsúlyt nehezen viseli el (6. táblázat).

A magyar rozsnok borítása 7-24\% tartományban módosul az N×P kölcsönhatások eredőjeként. Önmagában sem a növekvő N, sem a növekvô P kínálata nem okoz a kontrollhoz viszonyítva igazolható változást. Az extrém NP-túlkínálaton maximális a jelenléte. Tehát rendkívül trágyaigényes, de együtt igényli a két meghatározó tápelem bôségét. Ez szemmel láthatóan elmondható a taréjos búzafúre is, ahol a faj borítása még extrémebb módon, 0-32\% között módosul az N×P kölcsönhatások nyomán. Azzal a különbséggel, hogy a taréjos búzafú $\mathrm{N}$-igényessége már a P-ral gyengén ellátott talajon is kifejezetté vált, hiszen a 0\%-ról 15\%-ra emelkedett (6. táblázat). 
6. táblázat. Az $N \times P$ ellátottsági szintek hatása a gyep botanikai összetételére 2007. 05. 18-án (boritottsági \% a K-kezelések átlagában) (Mészlepedékes csernozjom vályogtalaj, Nagyhörcsök, Mezöföld) Dr. Szemán László felvételezése

\begin{tabular}{|c|c|c|c|c|c|c|}
\hline \multirow{2}{*}{$\begin{array}{c}\mathrm{AL}-\mathrm{P}_{2} \mathrm{O}_{5} \\
\mathrm{mg} / \mathrm{kg} \\
(1)\end{array}$} & \multicolumn{4}{|c|}{$\begin{array}{c}\text { N-trágyázás, } \mathrm{N} \mathrm{kg/ha/év} \\
\text { (2) }\end{array}$} & \multirow{2}{*}{$\begin{array}{l}\mathrm{SzD}_{5 \%} \\
\text { (3) }\end{array}$} & \multirow{2}{*}{$\begin{array}{c}\text { Átlag } \\
\text { (4) }\end{array}$} \\
\hline & 0 & 100 & 200 & 300 & & \\
\hline \multicolumn{7}{|c|}{ Nádképú csenkesz, \% (5) } \\
\hline 87 & 34 & 60 & 42 & 32 & & 42 \\
\hline 214 & 29 & 62 & 21 & 17 & 8 & 32 \\
\hline 444 & 33 & 59 & 19 & 10 & & 30 \\
\hline 704 & 29 & 61 & 17 & 10 & & 29 \\
\hline Átlag (4) & 31 & 61 & 25 & 17 & 4 & 34 \\
\hline \multicolumn{7}{|c|}{ Magyar rozsnok, \% (6) } \\
\hline 87 & 7 & 8 & 7 & 9 & & 8 \\
\hline 214 & 11 & 10 & 21 & 20 & 6 & 16 \\
\hline 444 & 9 & 14 & 23 & 21 & & 17 \\
\hline 704 & 11 & 9 & 23 & 24 & & 17 \\
\hline Átlag (4) & 9 & 10 & 18 & 19 & 3 & 14 \\
\hline \multicolumn{7}{|c|}{ Taréjos búzafú, \% (7) } \\
\hline 87 & 0 & 2 & 14 & 15 & & 8 \\
\hline 214 & $<1$ & 4 & 22 & 24 & 6 & 13 \\
\hline 444 & 0 & 3 & 26 & 24 & & 13 \\
\hline 704 & 0 & 4 & 29 & 32 & & 16 \\
\hline Átlag (4) & $<1$ & 3 & 22 & 24 & 3 & 12 \\
\hline \multicolumn{7}{|c|}{ Csomós ebír, \% (8) } \\
\hline Átlag (4) & $<1$ & 8 & 6 & 6 & 3 & 5 \\
\hline \multicolumn{7}{|c|}{ Vörös csenkesz, \% (9) } \\
\hline Átlag (4) & 6 & 0 & 0 & 0 & 3 & 2 \\
\hline \multicolumn{7}{|c|}{ Összes borítottság, \% (gyepfajok + gyom) (10) } \\
\hline 87 & 52 & 78 & 73 & 71 & & 69 \\
\hline 214 & 53 & 90 & 78 & 74 & 6 & 74 \\
\hline 444 & 55 & 88 & 78 & 70 & & 73 \\
\hline 704 & 52 & 88 & 81 & 79 & & 75 \\
\hline Átlag (4) & 53 & 86 & 77 & 74 & 3 & 73 \\
\hline
\end{tabular}

Megjegyzés: AL- $\mathrm{P}_{2} \mathrm{O}_{5}$ tartalmak a feltalajban 2005-ben mérve. A gyomborítás 5\%, a Zöld pántlikafú $1 \%$ átlagosan.

Table 6. Effect of $\mathrm{N} \times \mathrm{P}$ supply levels on the botanical composition of grass on 18 May 2007. Coverage $\%$ as a mean of K-treatments. (Calcareous loamy chernozem, Nagyhörcsök, Mezőföld region). Survey made by dr. László Szemán. (1) Ammoniumlactate-soluble $\mathrm{P}_{2} \mathrm{O}_{5} \mathrm{mg} / \mathrm{kg}$ in the plow-layer, (2) $\mathrm{N}$ $\mathrm{kg} / \mathrm{ha} / \mathrm{year}$, (3) $\mathrm{LSD}_{5 \%}$, (4) Mean, (5) Tall fescue, \%, (6) Smooth brome, \%, (7) Crested wheatgrass, \%, (8) Cocksfoot, \%, (9) Red fescue, \%, (10) Total coverage, \% (grass + weeds). Note: Ammoniumlactatesoluble $\mathrm{P}_{2} \mathrm{O}_{5} \mathrm{mg} / \mathrm{kg}$ in the plow-layer was measured in 2005 . Cover of weeds: $5 \%$, reed canarygrass: $1 \%$ as an average. 
7. táblázat. Az N×P ellátottsági szintek hatása a gyep botanikai összetételére 2008.

05. 19-én (borítottsági \% a K-kezelések átlagában)

(Mészlepedékes csernozjom vályogtalaj, Nagyhörcsök, Mezöföld)

Dr. Szemán László felvételezése

\begin{tabular}{|c|c|c|c|c|c|c|}
\hline \multirow{2}{*}{$\begin{array}{c}\mathrm{AL}-\mathrm{P}_{2} \mathrm{O}_{5} \\
\mathrm{mg} / \mathrm{kg} \\
\text { (1) }\end{array}$} & \multicolumn{4}{|c|}{$\begin{array}{c}\text { N-trágyázás, } \mathrm{N} \mathrm{kg/ha/év} \\
\text { (2) }\end{array}$} & \multirow[t]{2}{*}{$\begin{array}{l}\mathrm{SzD}_{5 \%} \\
\text { (3) }\end{array}$} & \multirow[t]{2}{*}{$\begin{array}{c}\text { Átlag } \\
\text { (4) }\end{array}$} \\
\hline & 0 & 100 & 200 & 300 & & \\
\hline \multicolumn{7}{|c|}{ Nádképú csenkesz, \% (5) } \\
\hline 87 & 34 & 60 & 43 & 34 & & 43 \\
\hline 214 & 39 & 61 & 11 & 8 & 6 & 30 \\
\hline 444 & 36 & 53 & 15 & 7 & & 28 \\
\hline 704 & 39 & 60 & 14 & 6 & & 30 \\
\hline Átlag (4) & 37 & 58 & 21 & 14 & 3 & 32 \\
\hline \multicolumn{7}{|c|}{ Magyar rozsnok, \% (6) } \\
\hline 87 & 8 & 10 & 10 & 12 & & 10 \\
\hline 214 & 6 & 15 & 25 & 30 & 6 & 19 \\
\hline 444 & 8 & 16 & 23 & 28 & & 19 \\
\hline 704 & 8 & 12 & 24 & 28 & & 18 \\
\hline Átlag (4) & 8 & 13 & 20 & 25 & 3 & 16 \\
\hline \multicolumn{7}{|c|}{ Taréjos búzafú, \% (7) } \\
\hline 87 & 0 & 1 & 16 & 15 & & 8 \\
\hline 214 & 0 & 0 & 28 & 24 & 4 & 13 \\
\hline 444 & 0 & 5 & 27 & 26 & & 14 \\
\hline 704 & 0 & 1 & 29 & 33 & & 16 \\
\hline Átlag (4) & 0 & 2 & 25 & 25 & 2 & 13 \\
\hline \multicolumn{7}{|c|}{ Csomós ebír, \% (8) } \\
\hline Átlag (4) & 1 & 9 & 7 & 8 & 3 & 6 \\
\hline \multicolumn{7}{|c|}{ Zöld pántlikafű, \% (9) } \\
\hline Átlag (4) & 0 & $<1$ & 1 & 3 & 3 & 1 \\
\hline \multicolumn{7}{|c|}{ Összes borítottság, \% (gyepfajok + gyom) (10) } \\
\hline 87 & 48 & 84 & 84 & 77 & & 73 \\
\hline 214 & 50 & 92 & 81 & 83 & 4 & 77 \\
\hline 444 & 52 & 91 & 81 & 79 & & 76 \\
\hline 704 & 54 & 90 & 80 & 82 & & 77 \\
\hline Átlag (4) & 51 & 89 & 81 & 80 & 2 & 76 \\
\hline
\end{tabular}

Megjegyzés: AL- $\mathrm{P}_{2} \mathrm{O}_{5}$ tartalmak a feltalajban 2005-ben mérve. A gyomborítás $7 \%$ átlagosan.

Table 7. Effect of $\mathrm{N} \times \mathrm{P}$ supply levels on the botanical composition of grass on 19 May 2008. Coverage $\%$ as a mean of K-treatments. (Calcareous loamy chernozem, Nagyhörcsök, Mezőföld region). Survey made by dr. László Szemán. (1) Ammoniumlactate-soluble $\mathrm{P}_{2} \mathrm{O}_{5} \mathrm{mg} / \mathrm{kg}$ in the plow-layer, (2) $\mathrm{N}$ $\mathrm{kg} / \mathrm{ha} /$ year, (3) $\mathrm{LSD}_{5 \%}$, (4) Mean, (5) Tall fescue, \%, (6) Smooth brome, \%, (7) Crested whestgrass, \%, (8) Cocksfoot, \%, (9) Reed canarygrass, \%, (10) Total coverage, \% (grass + weeds). Note: Ammoniumlactate-soluble $\mathrm{P}_{2} \mathrm{O}_{5} \mathrm{mg} / \mathrm{kg}$ in the plow-layer was measured in 2005 . Cover of weeds: $7 \%$ as an average. 
8. táblázat. Az $N \times P$ ellátottsági szintek hatása a gyep botanikai összetételére 2009. 05. 19-én (boritottsági \% a K-kezelések átlagában) (Mészlepedékes csernozjom vályogtalaj, Nagyhörcsök, Mezöföld) Dr. Szemán László felvételezése

\begin{tabular}{|c|c|c|c|c|c|c|}
\hline \multirow{2}{*}{$\begin{array}{c}\mathrm{AL}-\mathrm{P}_{2} \mathrm{O}_{5} \\
\mathrm{mg} / \mathrm{kg} \\
(1)\end{array}$} & \multicolumn{4}{|c|}{ N-trágyázás, $\mathrm{N} \mathrm{kg/ha/év}$} & \multirow{2}{*}{$\begin{array}{c}\mathrm{SzD}_{5 \%} \\
\text { (3) }\end{array}$} & \multirow[t]{2}{*}{$\begin{array}{c}\text { Átlag } \\
\text { (4) }\end{array}$} \\
\hline & 0 & 100 & 200 & 300 & & \\
\hline \multicolumn{7}{|c|}{ Nádképú csenkesz, \% (5) } \\
\hline 87 & 43 & 49 & 20 & 16 & & 32 \\
\hline 214 & 44 & 45 & 6 & 3 & 6 & 24 \\
\hline 444 & 46 & 46 & 5 & 4 & & 25 \\
\hline 704 & 46 & 44 & 6 & 2 & & 24 \\
\hline Átlag (4) & 45 & 46 & 9 & 6 & 3 & 26 \\
\hline \multicolumn{7}{|c|}{ Taréjos búzafú, \% (6) } \\
\hline 87 & 0 & 1 & 21 & 19 & & 10 \\
\hline 214 & 0 & 4 & 30 & 25 & 6 & 15 \\
\hline 444 & 0 & 3 & 28 & 26 & & 14 \\
\hline 704 & 0 & 6 & 35 & 31 & & 18 \\
\hline Átlag (4) & 0 & 3 & 28 & 26 & 3 & 14 \\
\hline \multicolumn{7}{|c|}{ Magyar rozsnok, \% (7) } \\
\hline 87 & 9 & 12 & 9 & 12 & & 11 \\
\hline 214 & 12 & 19 & 18 & 18 & 6 & 16 \\
\hline 444 & 12 & 16 & 14 & 16 & & 14 \\
\hline 704 & 11 & 16 & 16 & 14 & & 14 \\
\hline Átlag (4) & 11 & 16 & 14 & 15 & 3 & 14 \\
\hline \multicolumn{7}{|c|}{ Csomós ebír, \% (8) } \\
\hline Átlag (4) & 1 & 5 & 3 & 2 & 2 & 3 \\
\hline \multicolumn{7}{|c|}{ Gyomok, \% (9) } \\
\hline Átlag (4) & 8 & 6 & 5 & 6 & 2 & 6 \\
\hline \multicolumn{7}{|c|}{ Összes borítottság, \% (gyepfajok + gyom) (10) } \\
\hline 87 & 63 & 70 & 62 & 59 & & 64 \\
\hline 214 & 65 & 79 & 61 & 56 & 8 & 65 \\
\hline 444 & 69 & 76 & 55 & 53 & & 63 \\
\hline 704 & 66 & 79 & 63 & 55 & & 66 \\
\hline Átlag (4) & 66 & 76 & 60 & 56 & 4 & 64 \\
\hline
\end{tabular}

Megjegyzés: AL- $\mathrm{P}_{2} \mathrm{O}_{5}$ tartalmak a feltalajban 2005-ben mérve.

Table 8. Effect of $\mathrm{N} \times \mathrm{P}$ supply levels on the botanical composition of grass on 19 May 2009. Coverage $\%$ as a mean of K-treatments. (Calcareous loamy chernozem, Nagyhörcsök, Mezőföld region). Survey made by dr. László Szemán. (1) Ammoniumlactate-soluble $\mathrm{P}_{2} \mathrm{O}_{5} \mathrm{mg} / \mathrm{kg}$ in the plow-layer, (2) $\mathrm{N}$ $\mathrm{kg} / \mathrm{ha} /$ year, (3) $\mathrm{LSD}_{5 \%}$, (4) Mean, (5) Tall fescue, \%, (6) Crested wheatgrass, \%, (7) Smooth brome, \%, (8) Cocksfoot, \%, (9) Weeds, \%, (10) Total coverage, \% (grass + weeds). Note: Ammoniumlactate-soluble $\mathrm{P}_{2} \mathrm{O}_{5} \mathrm{mg} / \mathrm{kg}$ in the in the plow-layer was measured in 2005. 
A csomós ebír és a vörös csenkesz borítottságát a P-kínálat igazolhatóan nem befolyásolta, ezért a P-kezelések átlagában közöljük a N-hatásokat. E két faj tehát nem bizonyult P-igényesnek. A csomós ebír mérsékelt N-reakciót mutatott $100 \mathrm{~kg} / \mathrm{ha} /$ év körüli optimummal, de a N túlsúlyával sem mérséklődik igazolhatóan a borítottság. A vörös csenkesz viszont már a $100 \mathrm{~kg} / \mathrm{ha} / \mathrm{e} v$ N-adagú kezelésekben kipusztult. Úgy túnik igénytelen faj e tekintetben, mert trágyaigényét a 34 éve trágyázásban nem részesült NP-kontroll talajon is fedezni tudta.

Az összes borítottság 73\%-ot tett ki ebben az évben. A gyomok ebből 5, a zöld pántlikafú 1\%-ot képviselt átlagosan. A N-hiányos parcellákon 53\%, az N $100 \mathrm{~kg} / \mathrm{ha}$ /év kezelésekben $86 \%$ borítást mértünk. A N-túlsúllyal a borítottság az optimálishoz képest 12\%-kal, 74\%-ra esett vissza. Maximális összes borítás a mérsékelt $\mathrm{N}_{1} \mathrm{P}_{1}$ szinten jelentkezett 90\%-kal (6. táblázat).

Gyomnövény a parcellák több mint felén fordult elő nagyobb tömegben a N-kontroll és a N-nel gazdagon ellátott kezelésekben. Az egyes parcellákon 0-10\% összes gyomborítás volt megfigyelhetô, ami az egész kísérletben átlagosan 4,7\% borítottságot eredményezett. Jellemzó fajok a vadrezeda, apró szulák, mezei acat, kanadai betyárkóró, pásztortáska és tarackbúza. Az alacsony $\mathrm{N}$ szintû kezelések hatására a korábbi évekhez képest egyre több pillangós települt be: egyes parcellákon a komlós lucerna és a lednek 10\% borítási is elért, de csüdfú, fehérhere és kaszanyúg bükköny is jelen volt.

Hasonló kép tárul elénk a 7. táblázatban közölt 2008. évi felvételezés kapcsán. Azzal a különbséggel, hogy az utóbbi évben a vörös csenkesz már egyáltalán nem volt azonosítható, míg a zöld pántlikafú 3\%-os borítást produkált a maximális N-adaggal. Viszont nem fordult elố a N-kontroll parcellákon. Az elôzô évek viszonylag gyommentes $100 \mathrm{~kg} / \mathrm{ha} /$ év N kezelései is egyre gyomosabbak. A N kontroll parcellákra továbbra is elsôsorban a pillangós fajok betelepülése jellemző. A gyomfajok az előző évihez hasonlóak voltak.

2009-ben a nádképú csenkesz sem érdemi N, sem érdemi P hatásokat nem jelez, az NP-túlsúlyos parcellákon borítása 2\%-ra süllyed, csaknem kipusztul. A taréjos búzafú versenyképessége továbbra is az NP-túltrágyázott talajon kiemelkedő az előzó években megfigyeltekhez hasonlóan. A magyar rozsnok borítási maximuma a mérsékelt $\mathrm{N}_{1} \mathrm{P}_{1}$ kezeléskombinációhoz kötôdik, a bôségesebb NP-trágyázás már nem növelte részarányát. A csomós ebír átlagosan 3\%-ot képviselt a gyepben, emelkedettebb borítás az $\mathrm{N}_{1}$ szinten azonosítható. A gyomok 6\%-os részarányt mutattak a kezelésektôl lényegében függetlenül. A N-kontroll parcellákon a pillangósok tovább terjeszkedtek, borításuk nem ritkán elérte a 
15\%-ot, sôt az egyik parcella felét beborította a bükköny. Az összes növényi borítás maximumát az $\mathrm{N}_{1} \mathrm{P}_{1}$ szint jelenti, mind a N-hiány, mind a N-túlsúly nyomán a borítottság igazolhatóan visszaesik (8. táblázat).

\section{Köszönetnyilvánítás}

A kutatás a 49042 és 68665 sz. OTKA, valamint a CRO-13/2006 sz. pályázat eredményeként az NKTH és a KPI támogatásával jött létre, mely támogatás forrása a Kutatási és Technológiai Innovációs Alap.

\section{IRODALOM}

Bánszki T.: 1988. NPK mútrágya mennyiségi és aránykísérlet intenzív telepített gyepen. Növénytermelés. 37. 3: 247-257.

Bánszki T.: 1991. Fû́és gyepkeverék mútrágyázásának értékelése. [In: Vinczeffy I. (szerk.) Legelố az emberiség szolgálatában.] DATE Debrecen. 18-117.

Bánszki T.: 1997. Telepített gyep NPK mútrágyázása csernozjom talajon. Növénytermelés. 46. 5: 499-508.

Barcsák Z.: 1999. A gyepek tápanyagellátása. [In: Füleky Gy. (szerk.) Tápanyaggazdálkodás. Mezógazda Kiadó. Budapest. 522-535.

Barcsák Z.: 2004. Biogyepgazdálkodás. Mezôgazda Kiadó. Budapest.

Egnér, H.-Riehm, H.-Domingo, W. R.: 1960. Untersuchungen über die chemische Bodenanalyse als Grundlage für die Beurteilung des Nährstoffzustandes der Böden. II. K. Lantbr. Högsk. Ann. 26: 199-215.

Geisler, G.: 1988. Pflanzenbau. 2. Auflage. Paul Parey. Berlin und Hamburg.

Gruber F.: 1960. Rét és legelő. Mezőgazdasági Kiadó. Budapest.

ISO 11261: 1995. Soil Quality. Determination of total nitrogen. Modified Kjeldahl method.

Kádár I.: 1992. A növénytáplálás alapelvei és módszerei. MTA Talajtani és Agrokémiai Kutató Intézete. Budapest.

Kádár I.: 2004a. Mútrágyázás hatása a telepített gyep termésére és N-felvételére. 1. Gyepgazd. Közl. 2: 36-45.

Kádár I.: 2004b. Mútrágyázás hatása a telepített gyep ásványi elemtartalmára. 3. Gyepgazd. Közl. 2: 57-66.

Kádár I.: 2007a. Mútrágyahatások vizsgálata 4. éves telepített gyepen. Termés, elemösszetétel. Növénytermelés. 56. 5-6: 363-376.

Kádár I.: 2007b. Mútrágyahatások vizsgálata 4. éves telepített gyepen. Elemfelvétel, elemforgalom. Növénytermelés. 57. 1: 9-20.

Kádár I.-Németh T.: 1993. Nitrát bemosódásának vizsgálata mútrágyázási kísérletben. Növénytermelés. 42. 3: 331-338. 
Kjeldahl, J.: 1891. Neue Methode zur Bestimmung des Stickstoffs in organischen Körpern. Zeitschr. F. analyt. Chemie. 22: 366-382.

Klapp, E.: 1965. Die Düngung der Wiesen und Weiden. [In: Linser H. (ed.) Handbuch der Pflanzenernährung und Düngung. III.] Band. Springer Verlag. Wien-New York. 764-795.

Klapp, E.: 1971. Wiesen und Weiden. P. Parey. 4. Auflage. Berlin.

Lakanen, E.-Erviö, R.: 1971. A comparison of eight extractants for the determination of plant available microelements in soils. Acta Agr. Fenn. 123: 223-232.

McLeod, L. B.: 1965. Effect of nitrogen and potassium fertilization on the yield, regrowth, and carbohydrate content of the storage organ of alfalfa and grasses. Agron. J. 87. 4: 345-350.

Nagy G.: 2003. A gyepgazdálkodásra ható gazdasági-társadalmi környezet. [In: Nagy G. (szerk.) Debreceni Gyepgazdálkodási Napok.] Agrártudományi Centrum. Debrecen. 19: 7-19.

Németh T.-Kádár I.: 1999. Nitrát bemosódásának vizsgálata és a N-mérlegek alakulása egy mútrágyázási tartamkísérletben. Növénytermelés. 48. 3: 377-386.

Peters, A.-Janssens, F.: 1998. Species-rich grasslands: diagnostic,restoration and use in intensive livestock production system. [In: Nagy, G.-Petô, K. (eds.) Grassland Science in Europe.] EGF-DATE. Debrecen. 3: 375-393.

Schüpbach, H.: 1990. Futterbauliche und landwirtschaftpflegerische Aspekte artenreicher Naturwiesen in der Schweiz. [In: BAL Bericht. Bundesanst. f.] Alpenl. Landw. Bumpenstein. 1-12.

Szabó J.: 1977. Gyepgazdálkodás. Mezógazdasági Kiadó. Budapest.

Szemán L.: 2002. Telepített gyepek faji összetételének és tápanyagellátásának hatása a nyersfehérje tartalomra. [In: Jávor A.-Sárvári M. (szerk.) Innováció.] DE Mg. Tud. Kar. Debrecen. 219-233.

Szemán L.: 2007. Gyepgazdálkodási módszertan. Egyetemi jegyzet. SzIE. MKK. Gödöllô. 5-123.

Thamm F.-né: 1990. Növényminták nitráttartalmának meghatározását befolyásoló tényezők vizsgálata. Agrokémia és Talajtan. 39: 191-206.

Vinczeffy I.: 1998. Lehetôségeink a legeltetéses állattartásban. Tanulmány. Debreceni Gyepgazdálkodási Napok. 16. DATE. Debrecen.

Vinczeffy I.: 1999. Fontosabb ökológiai jellemzôk. [In: Agroökológia-Gyep-Vidékfejlesztés. Debreceni Gyepgazdálkodási Napok. 15. DATE. Debrecen. 15: 51-54.

Voisin, A.: 1961. Lebendige Grasnarbe. BLV Verlagsgesellschaft. München.

Voisin, A.: 1964. A talaj és a növényzet, az állat és az ember sorsa. Mezőgazdasági Kiadó. Budapest.

Voisin, A.: 1965. Fertilizer application. Soil, plant, animal. Crosby Lockwood. London. 
A szerzők levelezési címe - Adress of the authors:

Dr. Szemán László

Szent István Egyetem Gyepgazdálkodási Osztály

Gödöllő

Páter Károly u. 1.

H-2103

Dr. Kádár Imre-Ragályi Péter

MTA Talajtani és Agrokémiai Kutatóintézet

Budapest

Herman Ottó út 15.

H-1022 